\title{
PENGARUH PENAMBAHAN SERAT KACA TERHADAP KEKASARAN PERMUKAAN DAN PENYERAPAN AIR BAHAN BASIS GIGI TIRUAN NILON TERMOPLASTIK
}

\author{
(EFFECT OF FIBER GLASS ADDITION TO SURFACE ROUGHNESS AND WATER \\ SORPTION THERMOPLASTIC NYLON DENTURE BASE MATERIAL)
}

\author{
Ariyani, Tiffany \\ Departemen Prostodonsia \\ Fakultas Kedokteran Gigi, Universitas Sumatera Utara \\ Jl. Alumni No. 2 Kampus USU Medan 20155 \\ E-mail: ariyanidrg@yahoo.com
}

\begin{abstract}
The utilization of thermoplastic nylon as denture base has developed at the present time. However, beside the superiority in esthetic aspect, thermoplastic nylon denture base material also has susceptibility such as low color stability. It is difficult to polish resulting in a rougher surface and high water sorption. One of the methods in reducing water sorption is the addition of fiber glass to denture base material. The addition of fiber glass can also increase the surface roughness. This study was aimed to determine the effect of the addition of fiber glass to surface roughness and water sorption of thermoplastic nylon denture base material without and with fiber glass addition. This is a laboratory experimental research. The samples in this study used thermoplastic nylon, cylindrical, with diameter $15 \pm 1 \mathrm{~mm}$ and a thickness of 0.5 $\pm 0.1 \mathrm{~mm}$. The number of samples was 32 with 8 samples for each group. Samples were tested for surface roughness and water sorption values. Statistical analyses using one way ANOVA and LSD test showed that there were significant differences in surface roughness $p=0.0001(\mathrm{p}<0.05)$ and water sorption $\mathrm{p}=0.001(\mathrm{p}<0.05)$ among the groups. In conclusion, addition of fiber glass $0.5 \%, 1 \%$, and $1.5 \%$ on thermoplastic nylon denture base material can reduce water sorption and increase the surface roughness of thermoplastic nylon denture base material.
\end{abstract}

Key words: thermoplastic nylon, fiber glass, surface roughness, water sorption

\begin{abstract}
Abstrak
Penggunaan bahan nilon termoplastik sebagai bahan basis gigi tiruan berkembang pada masa sekarang ini, namun disamping kelebihannya dalam hal estetis, bahan basis gigi tiruan nilon termoplastik juga memiliki kekurangan yaitu stabilitas warna yang rendah, sulit dipoles sehingga menghasilkan permukaan yang lebih kasar dan penyerapan air yang tinggi. Salah satu metode untuk mengurangi penyerapan air adalah dengan menambahkan serat kaca pada bahan basis gigi tiruan. Penelitian ini bertujuan untuk mengetahui pengaruh penambahan serat kaca terhadap kekasaran permukaan dan penyerapan air bahan basis gigi tiruan nilon termoplastik tanpa dan dengan penambahan serat kaca. Jenis penelitian ini adalah eksperimental laboratoris. Sampel pada penelitian ini adalah nilon termoplastik berbentuk silindris berukuran diameter $15 \pm 1 \mathrm{~mm}$ dan ketebalan $0,5 \pm 0,1 \mathrm{~mm}$. Jumlah seluruh sampel adalah 32 dengan 8 sampel untuk setiap kelompok. Sampel tersebut di uji nilai kekasaran permukaan dan penyerapan air. Analisis statistik menggunakan uji ANOVA satu arah dan LSD menunjukkan terdapat perbedaan signifikan terhadap kekasaran permukaan dengan nilai $\mathrm{p}=$ $0,0001(\mathrm{p}<0,05)$ dan terhadap penyerapan air $\mathrm{p}=0,001(\mathrm{p}<0,05)$. Sebagai kesimpulan, penambahan serat kaca $0,5 \%$, $1 \%$, dan $1,5 \%$ pada bahan basis gigi tiruan nilon termoplastik dapat menurunkan nilai penyerapan air dan meningkatkan kekasaran permukaan bahan basis gigi tiruan nilon termoplastik.
\end{abstract}

Kata kunci: nilon termoplastik, serat kaca, kekasaran permukaan, penyerapan air

\section{PENDAHULUAN}

Basis gigi tiruan didefinisikan sebagai bagian dari gigi tiruan yang bersandar pada jaringan lunak rongga mulut, sekaligus sebagai tempat melekatnya anasir gigi tiruan. Pembuatan basis gigi tiruan perlu memperhatikan sifat material bahan yang digunakan, baik sifat fisis, mekanis, kemis maupun biologis. ${ }^{1}$ Syarat-syarat basis gigi tiruan yang ideal yaitu biokompatibel, penyerapan air yang rendah, stabilitas warna dan stabilitas dimensi yang baik, mudah dimanipulasi, mudah diperbaiki, tidak toksik atau 
iritan, radiopak, memiliki kekuatan mekanik yang baik termasuk kekuatan transversal, kekuatan impak, fati$q u e$, dan modulus elastisitas yang tinggi serta memiliki konduktivitas termal yang baik. ${ }^{1-3}$

Nilon termoplastik merupakan bahan basis gigi tiruan yang diperkenalkan pada tahun 1950 dan menjadi gigi tiruan fleksibel yang pertama di dunia. Pada awalnya penggunaan basis gigi tiruan nilon termoplastik hanya pada kasus-kasus tertentu seperti fraktur basis gigi tiruan yang berulang serta untuk pasien yang alergi terhadap basis gigi tiruan resin akrilik. Penggunaan nilon secara umum tidak direkomendasikan karena rentan untuk mengalami perubahan warna, penyerapan air yang tinggi dan peningkatan kekasaran permukaan setelah beberapa minggu pemakaian. ${ }^{4-6}$

Kekasaran permukaan merupakan awal tempat perlekatan sisa makanan yang akan terjadi pada pemakaian gigi tiruan setelah beberapa minggu. ${ }^{7}$ Gigi tiruan dengan permukaan yang kasar dapat menyebabkan perlekatan bakteri. ${ }^{7-10}$ Permukaan yang kasar pada basis gigi tiruan nilon termoplastik disebabkan nilon termoplastik memiliki titik leleh yang rendah sehingga bahan nilon termoplastik menjadi sulit untuk dipoles. ${ }^{7}$ Hasil beberapa penelitian in vitro menunjukkan bahwa jika suatu bahan basis gigi tiruan dengan kekasaran permukaan yang melebihi $0,2 \mu \mathrm{m}$ dapat meningkatkan level perlekatan kolonisasi bakteri. ${ }^{8}$ Hilgenberg yang mengutip pendapat Quirynen dkk. dan Bollen dkk. Menyatakan bahwa kekasaran permukaan dari bahan kedokteran gigi yang ideal adalah mendekati $0,2 \mu \mathrm{m}$ atau kurang. ${ }^{9}$

Rahal menyatakan bahwa penyerapan air pada basis gigi tiruan resin akrilik polimerisasi panas dipengaruhi oleh kondisi permukaan basis gigi tiruan tersebut dimana semakin kasar permukaannya maka penyerapan air semakin besar. ${ }^{11}$ Pada dasarnya penyerapan air suatu bahan basis gigi tiruan bergantung pada jenis bahan, struktur kimia rantai polimer, porositas dan ketebalan bahan tersebut. ${ }^{12,13}$ Selain itu, penyerapan air juga dipengaruhi oleh teknik pemolesan, kekasaran permukaan, monomer sisa dan lamanya perendaman. ${ }^{13-14}$ Penyerapan air yang tinggi pada bahan basis gigi tiruan nilon termoplastik terjadi karena molekul air yang masuk diantara rantai molekul disebabkan ikatan amida yang bersifat hidrofilik membentuk rantai utama resin poliamida. ${ }^{11}$ Berdasarkan International Standar Organization (ISO) 1567, nilai penyerapan air pada bahan basis gigi tiruan polimer harus lebih kecil atau sama dengan $32 \mu \mathrm{g} / \mathrm{mm}^{3}$. 1,12,11

Salah satu metode untuk mengurangi penyerapan air adalah dengan menambahkan serat kaca pada bahan basis gigi tiruan. ${ }^{2,5}$ Serat kaca merupakan serat yang paling banyak digunakan sebagai bahan penguat basis gigi tiruan. Hasil adhesi yang optimal antara serat kaca dan matriks polimer dapat dicapai dengan menambahkan silane coupling agent yang secara kimia mengikat serat kaca dan matriks polimer menjadi lebih kuat sehingga tercapai densitas yang optimal. ${ }^{2,10,15,16}$

Gurbuz dkk. yang mengutip pendapat Ladizesky dkk. yaitu kandungan serat yang tinggi akan mengurangi nilai penyerapan air sebesar $25 \% .{ }^{15}$ Hasil penelitian Sitorus menunjukkan bahwa nilai penyerapan air yang terendah terdapat pada resin akrilik polimerisasi panas (RAPP) dengan penambahan serat kaca potongan kecil ukuran $6 \mathrm{~mm}$ sedangkan nilai penyerapan air yang tertinggi terdapat pada RAPP tanpa penambahan serat kaca. ${ }^{17}$ Ariyani menemukan bahwa nilai penyerapan air yang terendah terdapat pada nilon termoplastik dengan penambahan serat kaca $1,5 \%$ sedangkan nilai

penyerapan air yang tertinggi terdapat pada nilon termoplastik tanpa penambahan serat kaca. Hal ini menunjukkan se-makin besar konsentrasi serat kaca yang ditambah-kan maka nilai penyerapan air akan semakin kecil. ${ }^{18}$

Penambahan serat kaca selain dapat mengurangi penyerapan air juga dapat meningkatkan kekasaran permukaan. ${ }^{8,10}$ Lee dkk. menemukan bahwa RAPP yang ditambahkan serat kaca akan menyebabkan ekstrusinya serat-serat tersebut di atas permukaan basis gigi tiruan. Lee dkk. menemukan bahwa penambahan serat kaca potongan kecil ukuran $3 \mathrm{~mm}$ dengan konsentrasi 9\% akan menyebabkan kekasaran permukaan RAPP meningkat secara signifikan. ${ }^{10}$ Zortuk menemukan bahwa penambahan serat kaca potongan kecil ukuran $3 \mathrm{~mm}$ dengan konsentrasi lebih dari $2 \%$ akan meningkatkan kekasaran permukaan RAPP sedangkan tidak terdapat perbedaan yang signifikan kekasaran permukaan RAPP pada penambahan serat kaca potongan kecil ukuran $3 \mathrm{~mm}$ dengan konsentrasi $0,5 \%$ dan $1 \% .^{8}$ Peningkatan kekasaran permukaan pada bahan basis gigi tiruan dipengaruhi oleh konsentrasi serat kaca yang ditambahkan dan ikatan kimia antara serat kaca dan matriks polimer. ${ }^{8,10}$ Tujuan penelitian ini adalah untuk mengetahui pengaruh penambahan serat kaca terhadap kekasaran permukaan dan penyerapan air bahan basis gigi tiruan nilon termoplastik tanpa dan dengan penambahan serat kaca.

\section{BAHAN DAN METODE}

Penelitian ini merupakan penelitian eksperimental laboratoris. Sampel pada penelitian ini adalah nilon termoplastik berbentuk silindris berukuran diameter $15 \pm 1 \mathrm{~mm}$ dan ketebalan $0,5 \pm 0,1 \mathrm{~mm}$. Jumlah sam- 
pel sebanyak 32 sampel untuk 4 kelompok.

Serat kaca ditimbang sebanyak 0,0075 gr untuk kelompok dengan penambahan serat kaca $0,5 \%$ dan 0,015gr untuk kelompok dengan penambahan serat kaca $1 \%$ serta 0,0225 gr untuk kelompok dengan penambahan serat kaca $1,5 \%$. Serat kaca dimasukkan dalam cairan silane coupling agent. Serat kaca dikeringkan dengan suhu kamar selama 40 menit dan kemudian dimasukkan ke dalam oven pemanas selama 1 jam pada suhu $115^{\circ} \mathrm{C}$ sebelum dimasukkan ke dalam nilon termoplastik. Nilon termoplastik ditimbang dengan timbangan digital sebanyak 12 gram, kemudian dimasukkan ke dalam suatu wadah. Nilon termoplastik dimasukkan ke dalam cartridge, kemudian masukkan sedikit serat kaca, setelah itu masukkan kembali nilon kemudian letakkan lagi serat kaca diatasnya, begitu seterusnya sampai bahan nilon dan serat kaca berada di dalam cartridge seluruhnya. Hal ini dilakukan dengan tujuan agar serat kaca tercampur merata pada bahan nilon termoplastik. Cartridge berisi bahan nilon termoplastik ditempatkan dalam furnace untuk melunakkan bahan nilon termoplastik dengan suhu 248,8$265,5^{\circ} \mathrm{C}$ selama 10 menit. Pada saat bahan nilon termoplastik mulai mencair dilakukan pengadukan sebanyak satu kali searah putaran jarum jam, kemudian diinjeksikan ke dalam kuvet. Selanjutnya sampel dilakukan penyelesaian akhir yaitu dirapikan dengan fraser bur untuk menghilangkan bagian yang tajam, Permukaan sampel dihaluskan dengan kertas pasir waterproof ukuran 800, 1000, dan 1200 yang dipasangkan pada rotary grinder dengan air mengalir masing-masing selama 5 menit dengan kecepatan $500 \mathrm{rpm}$. Untuk mencegah terlepasnya sampel pada saat pemolesan maka sampel diletakkan pada pemegang sampel yang terbuat dari stainless steel. Pemolesan dilanjutkan dengan Scotch-Brite brush yang dipasangkan pada polishing motor dengan kecepatan 500 rpm dan menggunakan coarse purnice hingga mengkilat.

Sampel yang telah dipoles, dilakukan pengukuran nilai kekasaran permukaan dengan menggunakan profile meter. Alat profile meter dikalibrasi. Sampel diletakkan di atas meja sejajar alat profile meter dan alat profile meter dijalankan. Pengukuran dilakukan sebanyak dua kali pada permukaan sampel yang dipoles. Pengukuran pertama dimulai dari salah satu tepi permukaan sampel yang telah ditandai dengan spidol, kemudian alat dijalankan dan membentuk suatu garis lurus melewati titik tengah sampel. Setelah hasil pengukuran pertama dicatat, sampel diputar $90^{\circ}$ dan alat dijalankan sehingga garis pengukuran kedua tegak lurus dengan garis pengukuran pertama. Hasil pengukuran kedua dicatat dan rata-rata dari kedua hasil pengukuran dihitung dan dicatat dengan satuan $\mu \mathrm{m}$. Kemudian, sampel dilakukan pengukuran nilai penyerapan air dengan menggunakan timbangan digital. Sampel yang telah dipoles disimpan dalam sebuah desikator pada suhu $37^{\circ} \mathrm{C}$ selama 24 jam untuk tujuan desikasi dan menghindari sampel berkontak dengan kelembaban luar. Proses desikasi diulang hingga sampel mengalami penurunan berat tidak melebihi $0,5 \mathrm{mg}$ dalam periode $24 \mathrm{jam}$. Setelah itu, sampel dikeluarkan dan ditimbang pada timbangan digital untuk mengetahui berat sampel sebelum direndam (M1). Sampel dari bahan basis gigi tiruan nilon termoplastik direndam dalam akuades dan disimpan dalam inkubator selama 7 hari pada suhu $37^{\circ} \mathrm{C}$. Setelah direndam selama 7 hari, sampel dikeluarkan dari air dan dibersihkan dengan kain bersih dan kering, kemudian sampel dibiarkan di udara terbuka selama 15 detik. Setelah 1 menit, sampel ditimbang kembali (M2). Sampel dimasukkan kembali ke dalam desikator sampai dicatat berat yang konstan. Setelah berat sampel konstan maka sampel ditimbang kembali (M3).

Nilai rerata dan standar deviasi dianalisis dengan uji univarian. Pengaruh penambahan serat kaca terhadap kekasaran permukaan dan penyerapan air pada bahan basis gigi tiruan nilon termoplastik diperoleh dengan analisis secara statistik dengan uji ANOVA satu arah. Untuk mengetahui perbedaan pengaruh penambahan serat kaca terhadap kekasaran permukaan dan penyerapan air digunakan uji statistik LSD.

\section{HASIL}

Nilai kekasaran permukaan bahan basis gigi tiruan nilon termoplastik tanpa dan dengan penambahan serat kaca pada penelitian ini diperoleh dengan menggunakan alat profile meter. Hasil penelitian menunjukkan nilai kekasaran permukaan yang terkecil pada kelompok A adalah $0,355 \mu \mathrm{m}$ dan nilai yang terbesar adalah $0,470 \mu \mathrm{m}$. Nilai kekasaran permukaan yang terkecil pada kelompok B adalah $0,660 \mu \mathrm{m}$ dan nilai yang terbesar adalah $0,825 \mu \mathrm{m}$. Nilai kekasaran permukaan yang terkecil pada kelompok $\mathrm{C}$ adalah $0,770 \mu \mathrm{m}$ dan nilai yang terbesar adalah $0,970 \mu \mathrm{m}$. Nilai kekasaran permukaan yang terkecil pada kelompok $\mathrm{D}$ adalah $1,135 \mu \mathrm{m}$ dan nilai yang terbesar adalah 1,700 $\mu \mathrm{m}$ (Tabel 1).

Nilai rerata kekasaran permukaan dianalisis dengan uji Univarian. Nilai rerata kekasaran permukaan pada kelompok A adalah 0,407 $\pm 0,040 \mu \mathrm{m}$. Nilai rerata kekasaran permukaan pada kelompok $\mathrm{B}$ adalah $0,748 \pm 0,063 \mu \mathrm{m}$. Nilai rerata kekasaran permukaan pada kelompok $\mathrm{C}$ adalah $0,851 \pm 0,068 \mu \mathrm{m}$. 
Nilai rerata kekasaran permukaan pada kelompok D adalah 1,343 $\pm 0,183 \mu \mathrm{m}$ (Tabel 1).

Tabel 1. Kekasaran permukaan bahan basis gigi tiruan nilon termoplastik tanpa dan dengan penambahan serat kaca potongan kecil ukuran $3 \mathrm{~mm}$ dengan konsentrasi $0,5 \%, 1 \%$, dan $1,5 \%$

\begin{tabular}{|c|c|c|c|c|}
\hline \multirow{2}{*}{$\begin{array}{c}\text { No. } \\
\text { sampel }\end{array}$} & \multicolumn{4}{|c|}{ Kekasaran Permukaan $(\mu \mathrm{m})$} \\
\hline & Kelompok A (Tanpa serat kaca) & Kelompok B (Serat kaca 0,5\%) & Kelompok C (Serat kaca 1\%) & Kelompok D (Serat kaca 1,5\%) \\
\hline 1 & $0,470^{*}$ & $0,825^{*}$ & 0,825 & 1,325 \\
\hline 2 & 0,450 & 0,690 & 0,785 & $1,135^{* *}$ \\
\hline 3 & 0,420 & 0,815 & 0,860 & 1,460 \\
\hline 4 & 0,360 & 0,710 & $0,770 * *$ & 1,415 \\
\hline 5 & 0,405 & 0,715 & 0,910 & 1,305 \\
\hline 6 & $0,355 * *$ & $0,660 * *$ & 0,805 & $1,700^{*}$ \\
\hline 7 & 0,390 & 0,765 & 0,880 & 1,175 \\
\hline \multirow[t]{3}{*}{8} & 0,405 & 0,805 & $0,970 *$ & 1,225 \\
\hline & $\overline{\mathrm{X}}_{-0407}$ & $\overline{\mathrm{X}}_{-0748}$ & $\overline{\mathrm{X}}_{-0851}$ & $\overline{\mathrm{X}}_{-1343}$ \\
\hline & $\mathrm{SD}=0,040$ & $\mathrm{SD}=0,063$ & $\mathrm{SD}=0,068$ & $\mathrm{SD}=0,183$ \\
\hline
\end{tabular}

Keterangan : * nilai terbesar

** nilai terkecil

Hasil statistik dengan ANOVA satu arah menunjukkan ada pengaruh penambahan serat kaca potongan kecil ukuran $3 \mathrm{~mm}$ dengan konsentrasi 0,5\%, 1\%, dan $1,5 \%$ terhadap kekasaran permukaan bahan basis gigi tiruan nilon termoplastik $\mathrm{p}=0,0001(\mathrm{p}<0,05)$ (Tabel 2).

Tabel 2. Pengaruh penambahan serat kaca potongan kecil ukuran 3 mm dengan konsentrasi 0,5\%, 1\%, dan $1,5 \%$ terhadap kekasaran permukaan bahan basis gigi tiruan nilon termoplastik

\begin{tabular}{cccc}
\hline \multirow{2}{*}{ Kelompok } & \multicolumn{3}{c}{ Kekasaran permukaan $(\mu \mathrm{m})$} \\
\cline { 2 - 4 } & $\mathrm{n}$ & $\overline{\mathrm{X}}_{ \pm \mathrm{SD}}$ & $\mathrm{p}$ \\
\hline $\mathrm{A}$ & 8 & $0,407 \pm 0,040$ & \\
$\mathrm{~B}$ & 8 & $0,748 \pm 0,063$ & $0,0001^{*}$ \\
$\mathrm{C}$ & 8 & $0,851 \pm 0,068$ & \\
$\mathrm{D}$ & 8 & $1,343 \pm 0,183$ & \\
\hline
\end{tabular}

Keterangan: * signifikan

Berdasarkan hasil uji LSD terlihat perbedaan signifikan antara kelompok A dengan kelompok $\mathrm{B}(\mathrm{p}=$ $0,001)$, kelompok A dengan kelompok $\mathrm{C}(\mathrm{p}=0,0001)$, kelompok A dengan kelompok $\mathrm{D}(\mathrm{p}=0,0001)$, kelompok $\mathrm{B}$ dengan kelompok $\mathrm{D}(\mathrm{p}=0,0001)$, dan kelompok $\mathrm{C}$ dengan kelompok $\mathrm{D}(\mathrm{p}=0,0001)$ tetapi tidak ada perbedaan antara kelompok B dengan kelompok C $(\mathrm{p}=0,059)($ Tabel 3).

Tabel 3. Perbedaan pengaruh penambahan serat kaca potongan kecil ukuran $3 \mathrm{~mm}$ dengan konsentrasi $0,5 \%, 1 \%$, dan $1,5 \%$ terhadap kekasaran permukaan bahan basis gigi tiruan nilon termoplastik

\begin{tabular}{cc}
\hline Perbedaan pengaruh kekasaran permukaan & $\mathrm{p}$ \\
\hline A dengan B & $0,0001^{*}$ \\
A dengan C & $0,0001^{*}$ \\
A dengan D & $0,0001^{*}$ \\
B dengan C & 0,059 \\
B dengan D & $0,0001^{*}$ \\
C dengan D & $0,0001^{*}$ \\
\hline
\end{tabular}

Keterangan : * signifikan
Nilai penyerapan air bahan basis gigi tiruan nilon termoplastik tanpa dan dengan penambahan serat kaca pada penelitian ini diperoleh dengan menghitung selisih antara berat sampel sesudah perendaman dan berat sampel sesudah perendaman yang kemudian dikeringkan dengan desikator dibagi dengan volume sampel sebesar $88,3125 \mathrm{~mm}^{3}$. Hasil penelitian menunjukkan nilai penyerapan air yang terkecil pada kelompok A adalah $14,720 \mu \mathrm{g} / \mathrm{mm}^{3}$ dan nilai yang terbesar adalah $24,912 \mu \mathrm{g} / \mathrm{mm}^{3}$. Nilai penyerapan air yang terkecil pada kelompok B adalah 13,589 $\mu \mathrm{g} /$ $\mathrm{mm}^{3}$ dan nilai yang terbesar adalah $21,514 \mu \mathrm{g} / \mathrm{mm}^{3}$. Nilai penyerapan air yang terkecil pada kelompok $\mathrm{C}$ adalah $11,323 \mu \mathrm{g} / \mathrm{mm}^{3}$ dan nilai yang terbesar adalah $19,250 \mu \mathrm{g} / \mathrm{mm}^{3}$. Nilai penyerapan air yang terkecil pada kelompok D adalah $10,191 \mu \mathrm{g} / \mathrm{mm}^{3}$ dan nilai yang terbesar adalah $16,985 \mu \mathrm{g} / \mathrm{mm}^{3}$ (Tabel 4).

Nilai rerata penyerapan air dianalisis dengan uji Univarian. Nilai rerata penyerapan air pada kelompok A adalah $20,241 \pm 3,552 \mu \mathrm{g} / \mathrm{mm}^{3}$. Nilai rerata penyerapan air pada kelompok B adalah 18,259 $\pm 2,668$ $\mu \mathrm{g} / \mathrm{mm}^{3}$. Nilai rerata penyerapan air pada kelompok $\mathrm{C}$ adalah $15,994 \pm 2,668 \mu \mathrm{g} / \mathrm{mm}^{3}$. Nilai rerata penyerapan air pada kelompok D adalah 14,155 $\pm 2,182$ $\mu \mathrm{g} / \mathrm{mm}^{3}$ (Tabel 4).

Hasil statistik dengan ANOVA satu arah menunjukkan ada pengaruh penambahan serat kaca potongan kecil ukuran $3 \mathrm{~mm}$ dengan konsentrasi 0,5\%, 1\%, dan $1,5 \%$ terhadap penyerapan air bahan basis gigi tiruan nilon termoplastik $\mathrm{p}=0,001(\mathrm{p}<0,05)($ Tabel 5).

Berdasarkan hasil uji LSD maka terlihat tidak ada perbedaan antara kelompok A dengan kelompok B $(\mathrm{p}=0,170)$, kelompok $\mathrm{B}$ dengan $\mathrm{C}(\mathrm{p}=0,118)$, dan kelompok $C$ dengan $D(p=0,201)$ serta terdapat perbedaan yang signifikan antara kelompok A dengan kelompok $\mathrm{C}(\mathrm{p}=0,005)$, kelompok A dengan kelompok 
$\mathrm{D}(\mathrm{p}=0,0001)$, dan kelompok B dengan kelompok $\mathrm{D}(\mathrm{p}=0,007)$ (Tabel 6).

Tabel 4. Penyerapan air bahan basis gigi tiruan nilon termoplastik tanpa dan dengan penambahan serat kaca potongan kecil ukuran $3 \mathrm{~mm}$ dengan konsentrasi $0,5 \%, 1 \%$, dan 1,5\%

\begin{tabular}{|c|c|c|c|c|c|}
\hline \multirow{2}{*}{ No. sampel } & \multicolumn{5}{|c|}{ Penyerapan Air $\left(\mu \mathrm{g} / \mathrm{mm}^{3}\right)$} \\
\hline & Kelompok A (Tanpa Serat Kaca) & Kelompok B (Serat Kaca 0,5\%) & Kelompok C (Serat Kaca 1\%) & Kelompok D (Serat & Kaca $1,5 \%)$ \\
\hline 1 & $24,912^{*}$ & 20,382 & 18,117 & 13,589 & \\
\hline 2 & 19,250 & $13,589 * *$ & 16,985 & 14,720 & \\
\hline 3 & 22,647 & 20,382 & $19,250 *$ & 13,589 & \\
\hline 4 & 18,117 & 15,853 & 14,720 & 15,853 & \\
\hline 5 & 21,514 & 18,117 & $11,323 * *$ & 12,456 & \\
\hline 6 & $14,720^{* *}$ & 19,250 & 15,853 & $10,191 * *$ & \\
\hline 7 & 23,779 & 16,985 & 18,117 & $16,985^{*}$ & \\
\hline \multirow[t]{3}{*}{8} & 16,985 & $21,514 *$ & 13,589 & 15,853 & \\
\hline & $\bar{X}_{=20,241}$ & $\overline{\mathrm{X}}_{=18,259}$ & $\overline{\mathrm{X}}_{=15,994}$ & $\overline{\mathrm{X}}_{=14,155}$ & \\
\hline & $\mathrm{SD}=3,552$ & $\mathrm{SD}=2,668$ & $\mathrm{SD}=2,668$ & $\mathrm{SD}=2,182$ & \\
\hline
\end{tabular}

Keterangan : * nilai terbesar

** nilai terkecil

Tabel 5. Pengaruh penambahan serat kaca potongan kecil ukuran 3 mm dengan konsentrasi 0,5\%, 1\%, dan $1,5 \%$ terhadap penyerapan air bahan basis gigi tiruan nilon termoplastik

\begin{tabular}{cccc}
\hline \multirow{2}{*}{ Kelompok } & \multicolumn{3}{c}{ Penyerapan Air $\left(\mu \mathrm{g} / \mathrm{mm}^{3}\right)$} \\
\cline { 2 - 4 } & $\mathrm{n}$ & $\overline{\mathrm{X}}_{ \pm \mathrm{SD}}$ & $\mathrm{p}$ \\
\hline A & 8 & $20,241 \pm 3,552$ & \\
B & 8 & $18,259 \pm 2,668$ & $0,001^{*}$ \\
C & 8 & $15,994 \pm 2,668$ & \\
D & 8 & $14,155 \pm 2,182$ & \\
\hline
\end{tabular}

Keterangan : * signifikan

Tabel 6. Perbedaan pengaruh penambahan serat kaca potongan kecil ukuran $3 \mathrm{~mm}$ dengan konsentrasi $0,5 \%, 1 \%$, dan $1,5 \%$ terhadap penyerapan air bahan basis gigi tiruan nilon termoplastik

\begin{tabular}{cc}
\hline Perbedaan pengaruh penyerapan air & $\mathrm{p}$ \\
\hline A dengan B & 0,170 \\
A dengan C & $0,005^{*}$ \\
A dengan D & $0,0001^{*}$ \\
B dengan C & 0,118 \\
B dengan D & $0,007^{*}$ \\
C dengan D & 0,201 \\
\hline
\end{tabular}

Keterangan : * signifikan

\section{PEMBAHASAN}

Pada Tabel 1 terlihat nilai kekasaran permukaan yang terkecil pada kelompok A adalah $0,355 \mu \mathrm{m}$ dan nilai yang terbesar adalah $0,470 \mu \mathrm{m}$. Nilai kekasaran permukaan yang terkecil pada kelompok B adalah $0,660 \mu \mathrm{m}$ dan nilai yang terbesar adalah $0,825 \mu \mathrm{m}$. Nilai kekasaran permukaan yang terkecil pada kelompok $\mathrm{C}$ adalah $0,770 \mu \mathrm{m}$ dan nilai yang terbesar adalah $0,970 \mu \mathrm{m}$. Nilai kekasaran permukaan yang terkecil pada kelompok $\mathrm{D}$ adalah $1,135 \mu \mathrm{m}$ dan nilai yang terbesar adalah 1,700 $\mu \mathrm{m}$. Berdasarkan hasil tersebut didapatkan nilai kekasaran permukaan yang bervariasi pada setiap sampel dalam satu kelompok, walau- pun masih dalam cakupan data yang homogen berdasarkan uji homogenitas (uji Levene). Hal ini dapat disebabkan kesulitan saat memegang dan menekan sampel pada alat rotary grinder yang dapat mempengaruhi permukaan sampel sehingga menyebabkan nilai kekasaran permukaan yang berbeda pada setiap sampel dalam satu kelompok yang sama. Nilai rerata kekasaran permukaan yang terkecil adalah pada kelompok tanpa penambahan serat kaca dan yang terbesar terdapat pada kelompok dengan penambahan serat kaca $1,5 \%$. Hasil penelitian menunjukkan semakin besar konsentrasi serat kaca yang ditambahkan maka nilai kekasaran permukaan akan semakin besar. Hal ini sesuai dengan penelitian yang dilakukan oleh Lee dkk. bahwa penambahan serat kaca akan menyebabkan kekasaran permukaan RAPP meningkat secara signifikan karena sulitnya pencampuran RAPP dengan serat kaca sehingga meningkatkan kekasaran permukaan. Pada penelitian ini, konsentrasi serat kaca yang digunakan adalah $0,5 \%, 1 \%$, dan $1,5 \%$, sedangkan pada penelitian Lee dkk. menggunakan serat kaca dengan konsentrasi $9 \% .{ }^{10}$ Begitu juga dengan penelitian yang dilakukan oleh Zortuk yang menemukan bahwa penambahan serat kaca akan meningkatkan kekasaran permukaan. Pada penelitian ini, konsentrasi serat kaca yang digunakan adalah $0,5 \%, 1 \%$, dan $1,5 \%$, sedangkan pada penelitian Zortuk menggunakan serat kaca dengan konsentrasi $0,5 \%$, $1 \%$, dan $2 \%{ }^{8}$

Hilgenberg yang mengutip pendapat Quirynen dkk. dan Bollen dkk. menyatakan bahwa kekasaran permukaan dari bahan kedokteran gigi yang ideal adalah mendekati $0,2 \mu \mathrm{m}$ atau kurang. ${ }^{12}$ Gigi tiruan dengan permukaan yang kasar dapat menyebabkan perlekatan bakteri. ${ }^{8,10} \mathrm{Hal}$ ini sesuai dengan hasil beberapa penelitian in vitro yaitu jika suatu bahan basis gigi tiruan dengan kekasaran permukaan yang melebihi $0,2 \mu \mathrm{m}$ dapat meningkatkan level perlekatan 
kolonisasi bakteri. ${ }^{8}$ Selain itu, permukaan yang kasar suatu restorasi juga dapat mengakibatkan perubahan warna pada basis gigi tiruan, ketidaknyamanan pada pasien dan kesulitan menjaga oral hygiene. $^{7-9}$

Pada tabel 3 hasil uji LSD (Least Significant Different) terlihat ada perbedaan pengaruh penambahan serat kaca potongan kecil ukuran $3 \mathrm{~mm}$ dengan konsentrasi $0,5 \%, 1 \%$, dan $1,5 \%$ terhadap kekasaran permukaan bahan basis gigi tiruan nilon termoplastik. Berdasarkan hasil uji LSD, terlihat perbedaan signifikan antara kelompok A dengan kelompok $\mathrm{B}(\mathrm{p}=0,0001)$, kelompok A dengan kelompok $\mathrm{C}(\mathrm{p}=$ $0,0001)$, kelompok A dengan kelompok $\mathrm{D}(\mathrm{p}=$ 0,0001), kelompok $\mathrm{B}$ dengan kelompok $\mathrm{D}(\mathrm{p}=$ 0,0001), dan kelompok $\mathrm{C}$ dengan kelompok $\mathrm{D}$ ( $\mathrm{p}=$ $0,0001)$ tetapi tidak ada perbedaan antara kelompok $\mathrm{B}$ dengan kelompok $\mathrm{C}(\mathrm{p}=0,059)$.

Hasil penelitian ini sesuai dengan hasil penelitian yang dilakukan oleh Zortuk yaitu tidak terdapat perbedaan yang signifikan kekasaran permukaan RAPP pada penambahan serat kaca potongan kecil ukuran $3 \mathrm{~mm}$ dengan konsentrasi $0,5 \%$ dan $1 \%{ }^{8} \mathrm{Pe}-$ nambahan serat kaca dengan konsentrasi $0,5 \%, 1 \%$, dan $1,5 \%$ dilakukan atas pertimbangan bahwa hasil penelitian Zortuk menunjukkan penambahan se-rat kaca potongan kecil ukuran $3 \mathrm{~mm}$ dengan konsentrasi lebih dari $2 \%$ akan meningkatkan kekasaran permukaan RAPP, sedangkan tidak terdapat perbedaan yang signifikan kekasaran permukaan RAPP pada penambahan serat kaca potongan kecil ukuran $3 \mathrm{~mm}$ dengan konsentrasi $0,5 \%$ dan $1 \%{ }^{8}$ Pada penelitian ini tidak ada perbedaan penambahan serat kaca dengan konsentrasi 0,5\% dan 1\% terhadap kekasaran permukaan bahan basis gigi tiruan nilon termoplastik.

Pada Tabel 4 terlihat nilai penyerapan air yang terkecil pada kelompok A adalah $14,720 \mu \mathrm{g} / \mathrm{mm}^{3}$ dan nilai yang terbesar adalah $24,912 \mu \mathrm{g} / \mathrm{mm}^{3}$. Nilai penyerapan air yang terkecil pada kelompok B adalah $13,589 \mu \mathrm{g} / \mathrm{mm}^{3}$ dan nilai yang terbesar adalah 21,514 $\mu \mathrm{g} / \mathrm{mm}^{3}$. Nilai penyerapan air yang terkecil pada kelompok $C$ adalah $11,323 \mu \mathrm{g} / \mathrm{mm}^{3}$ dan nilai yang terbesar adalah $19,250 \mu \mathrm{g} / \mathrm{mm}^{3}$. Nilai penyerapan air yang terkecil pada kelompok D adalah 10,191 $\mu \mathrm{g} /$ $\mathrm{mm}^{3}$ dan nilai yang terbesar adalah $16,985 \mu \mathrm{g} / \mathrm{mm}^{3}$. Berdasarkan hasil tersebut didapatkan nilai penyerapan air yang bervariasi pada setiap sampel dalam satu kelompok, walaupun masih dalam cakupan data yang homogen berdasarkan uji homogenitas (uji Levene). Hal ini mungkin dapat disebabkan sulitnya mengendalikan tebal sampel yang sama dalam satu kelompok, walaupun ketebalan tiap sampel masih dalam batas ukuran yang ditentukan $(0,5 \pm 0,1 \mathrm{~mm})$. Nilai rerata penyerapan air yang terkecil adalah pada kelompok dengan penambahan serat kaca 1,5\% dan yang terbesar terdapat pada kelompok tanpa penambahan serat kaca. Hasil penelitian menunjukkan semakin besar konsentrasi serat kaca yang ditambahkan maka nilai penyerapan air akan semakin rendah. Hal ini sesuai dengan penelitian yang dilakukan oleh Polat dkk, Gurbuz dkk, Sitorus dan Ariyani bahwa konsentrasi serat kaca yang ditambahkan pada bahan basis gigi tiruan dapat mempengaruhi nilai penyerapan air pada suatu bahan polimer. Polat dkk. meneliti perbedaan penyerapan air pada bahan polimer dengan teknik kompresi dan teknik injeksi dengan konsentrasi serat kaca $1 \%$, $3 \%$, dan 5\% serta ukuran $4 \mathrm{~mm}, 6 \mathrm{~mm}$, dan $8 \mathrm{~mm}$. Hasil penelitian menunjukkan nilai penyerapan air pada bahan polimer yang ditambahkan serat kaca dengan teknik injeksi lebih rendah dibandingkan dengan teknik kompresi dan semakin besar konsentrasi serat kaca yang digunakan maka nilai penyerapan air akan semakin rendah. ${ }^{19}$ Gurbuz dkk. meneliti penyerapan air pada bahan resin akrilik yang ditambahkan serat kaca yang disilanisasi dan yang tidak disilanisasi dengan konsentrasi serat kaca 5\%, 10\%, 15\%, dan $20 \%$. Hasil penelitian menunjukkan terdapat perbedaan yang signifikan antara kelompok yang disilanisasi dan yang tidak disilanisasi. ${ }^{15}$ Sitorus meneliti penyerapan air pada bahan basis gigi tiruan RAPP yang ditambahkan serat kaca potongan kecil ukuran $4 \mathrm{~mm}, 6 \mathrm{~mm}$, dan $8 \mathrm{~mm}$. Hasil penelitian menunjukkan bahwa nilai penyerapan air yang terendah terdapat pada RAPP dengan penambahan serat kaca potongan kecil ukuran $6 \mathrm{~mm}$ sedangkan nilai penyerapan air yang tertinggi terdapat pada RAPP tanpa penambahan serat kaca. ${ }^{17}$ Ariyani meneliti penyerapan air pada bahan basis gigi tiruan nilon termoplastik yang ditambahkan se-rat kaca potongan kecil ukuran $3 \mathrm{~mm}$ dengan kon-sentrasi $1 \%$ dan $1,5 \%$. Hasil penelitian menunjuk-kan bahwa nilai penyerapan air yang terendah ter-dapat pada nilon termoplastik dengan penambahan serat kaca $1,5 \%$ sedangkan nilai penyerapan air yang tertinggi terdapat pada nilon termoplastik tanpa penambahan serat kaca. ${ }^{18}$

Serat kaca memiliki beberapa keuntungan seperti mudah dimanipulasi,biokompatibel, tidak bersifat karsinogenik, memiliki estetis yang baik, dan memiliki modulus elastisitas yang tinggi serta dapat berikatan baik dengan matriks polimer. Serat kaca merupakan bahan yang paling cocok untuk digunakan pada kedokteran gigi karena estetisnya baik. ${ }^{2,8,10,16}$ Hasil adhesi yang optimal antara serat kaca dan matriks polimer dapat dicapai dengan menambahkan silane coupling agent yang secara kimia mengikat serat kaca dan matriks polimer menjadi lebih kuat sehingga tercapai densitas yang optimal. ${ }^{2,10,15,16}$ Bahan 
silane coupling agent yang paling sering digunakan adalah organosilanes [3-methacryloxy propyltrimethoxy silane $(\gamma$ - MPS)] sebagai bahan adhesif untuk meningkatkan interaksi antar molekul pada matriks polimer. Kegunannya adalah untuk meningkatkan sifat mekanis dan sifat fisis resin, serta untuk menyingkirkan air pada permukaan serat kaca. Ketika serat kaca dilapisi silane coupling agent dan dikeringkan, air disingkirkan sehingga terbentuk siloxane bridge dan terjadi reaksi kondensasi antara silanol dan permukaan serat kaca. Tanpa lapisan silane ikatan tersebut akan rusak disebabkan air masuk ke dalam resin dan akan terjadi proses readsorpsi pada permukaan serat kaca. ${ }^{16,18}$

Pada Tabel 6 hasil uji LSD (Least Significant Different) terlihat bahwa terdapat perbedaan pengaruh penambahan serat kaca potongan kecil ukuran $3 \mathrm{~mm}$ dengan konsentrasi $0,5 \%, 1 \%$, dan $1,5 \%$ terhadap penyerapan air bahan basis gigi tiruan nilon termoplastik. Berdasarkan hasil uji LSD terlihat tidak ada

\section{DAFTAR PUSTAKA}

1. McCabe JF, Walls AWG Applied dental materials. $9^{\text {th }}$ ed., London: Blackwell Munksgaard, 2008: 110-23.

2. Alla RK, Sajjan S, Alluri VR, Ginjupalli K,Upadhya $\mathrm{N}$. Influence of fiber reinforcement on the properties of denture base resins. JBNB 2013; 4: 91-7.

3. Noort R. Introduction to dental materials. $3^{\text {rd }}$ ed., London: Elsevier, 2007: 216-7.

4. Yunus N, Rashid AA, Azmi LL, Abu-Hassan MI. Some flexural properties of a nylon denture base polymer. J of Oral rehabilitation 2005; 32: 65-71.

5. Kohli S, Bhatia S. Polyamides in dentistry. Int $\mathbf{J}$ of Scientific Study 2013; 1(1): 20-5.

6. Sepulveda-Navarro WF, Arana-Correa BE, Borges CPF, Jorge JHJ, Urban VM, Campanha NH. Color stability of resins and nylon as denture base material in beverages. J of Prosthodontics 2011; 20: 632-8.

7. Abuzar MA, Bellur S, Duong N, Kim BB, Lu P, Palfreyman N, dkk. Evaluating surface roughness of a polyamide denture base material in comparison with poly(methyl methacrylate). J of Oral Science 2010; 52(4): 577-81.

8. Zortuk M, Kilic K, Uzun G, Ozturk A, Kesim B. The effect of different fiber concentrations on the surface roughness of provisional crown and fixed partial denture resin. Eur J Dent 2008; 2: 185-90.

9. Hilgenberg SP, Orellana-Jimenez EE, SepulvedaNavarro WF, Arana-Correa BE, Alves DCT, Campanha NH. Evaluation of surface physical properties of acrylic resins for provisional prosthesis. Mat Res 2008; 11(3): 257-60.

10. Lee SI, Lim YJ, Yun SD. Strength of glass fiber reinforced PMMA resin and surface roughness change after abrasion test. J Korean Acad Prosthopdont 2007; 45(3): 310-20. perbedaan antara kelompok A dengan kelompok B $(\mathrm{p}=0,170)$, kelompok $\mathrm{B}$ dengan $\mathrm{C}(\mathrm{p}=0,118)$, dan kelompok $\mathrm{C}$ dengan $\mathrm{D}(\mathrm{p}=0,201)$ serta terdapat perbedaan yang signifikan antara kelompok A dengan kelompok C ( $\mathrm{p}=0,005)$, kelompok A dengan kelompok $\mathrm{D}(\mathrm{p}=0,0001)$, dan kelompok $\mathrm{B}$ dengan kelompok D $(\mathrm{p}=0,007)$.

Hasil yang diperoleh pada penelitian ini adalah dengan penambahan serat kaca konsentrasi $0,5 \%$, $1 \%$ dan $1,5 \%$ pada bahan basis gigi tiruan nilon termoplastik dapat menurunkan nilai penyerapan air. Penambahan serat kaca dengan konsentrasi 0,5\%, $1 \%$, dan $1,5 \%$ dilakukan atas pertimbangan bahwa nilai penyerapan air akan menurun dengan meningkatnya konsentrasi serat kaca yang ditambahkan. Hal ini menunjukkan penambahan serat kaca dengan konsentrasi $1,5 \%$ paling efektif menurunkan nilai penyerapan air pada bahan basis gigi tiruan nilon termoplastik.

11. Takabayashi Y. Characteristics of denture thermoplastic resins for non-metal clasp dentures. Dent Material J 2010; 29(4): 353-61.

12. Pero AC, Marra J, Paleari AG de Souza RF, Ruvolo-Filho A, Compagnoni MA. Reability of a method for evaluating porosity in denture base resins. Gerodontology 2011; 28:127-33.

13. Tuna SH, Keyf F, Gumus HA, Uzun C. The evaluation of water sorption/solubility on various acrylic resins. European J of Dentistry 2008; 2: 191-7.

14. Rahal JS, Mesquita MF, Henriques GEP, Nobilo MAA. Influence of chemical and mechanical polishing on water sorption and solubility of denture base acrylic resins. Braz Dent J 2004; 15(3): 225-30.

15. Gürbüz Ö. Ünalan F, Kursoglu P. Water sorption of denture teeth acrylic resin reinforced with milled glass fiber. OHDMBCS 2005; 4(4): 57-62.

16. Loncar A, Vojvodic D, Jerolimov V, Komar D, Zabarovic D. Fibre reinforced polymers part II: Effect on mechanical properties. Acta Stomatol Croat 2008; 42(1): 49-63.

17. Sitorus Z, Dahar E. Perbaikan sifat fisis dan mekanis resin akrilik polimerisasi panas dengan penambahan serat kaca. Dentika dent J 2012; 17(1): 24-9.

18. Ariyani, Tamin H, Indra M. Pengaruh penambahan fiber glass reinforced terhadap penyerapan air dan stabilitas warna bahan basis gigi tiruan nilon termoplastik. Dentika dent J 2013; 17(3): 239-45.

19. Polat TN, Karacaer O, Tezvergil A, Lassila LVJ, Vallittu PK. Water sorption, solubility and dimensional changes of danture base polymers reinforced with short glass fibers. J Biomaterials Applications 2003; 17: 321-35 